DANUTA BORECKA-BIERNAT ID 0000-0003-1401-9821

Instytut Psychologii, Uniwersytet Wrocławski Department of Psychology, The University of Wrocław e-mail: danuta.borecka-biernat@uwr.edu.pl

\title{
Strategia agresywnego radzenia sobie młodzieży dorastającej w sytuacji konfliktu społecznego. Analiza osobowościowych i rodzinnych uwarunkowań
}

\section{Aggressive Coping Strategy of Adolescents in Social Conflict Situation. Analysis of Personality and Family Determinants}

\begin{abstract}
The aim of the study was to search for the personality and family predictors of an aggressive coping strategy of adolescents in the social conflict situation. The following tools were applied: Danuta Borecka-Biernat's Questionnaire to Study Strategies for Coping with a Social Conflict Situation by Adolescents (KSMK), Stress Evaluation Questionnaire (KOS) by Dorota Włodarczyk and Kazimierz Wrześniewski, Morris Rosenberg’s Self-Esteem Scale (RSES), Questionnaire to Study a Sense of Control (KBPK) by Grażyna Krasowicz and Anna Kurzyp-Wojnarska, Three-Factor State-Trait Anxiety Inventory (TISCO) by Charles Spielberg and K. Wrześniewski, Parental Attitudes Scale (SPR) by Mieczysław Plopa, and Questionnaire to Investigate Strategies for Coping with a Social Conflict Situation by Parents in the Perception of a Child (SRwSK) by Danuta Borecka-Biernat. The empirical research was carried out in the junior high schools and comprised 893 adolescent (468 girls and 425 boys) aged 13-15.

The research showed that judging the conflict as a threat, a higher evaluation of the physical characteristics of a young person, a strong belief in the influence of others on the positive and negative effects of the events, and the response with anger in interpersonal situations posing a threat to 'I' coincide with an aggressive coping strategy of adolescents in the social conflict situation.

Moreover, the analysis of the results has shown that the adolescents' aggressive way of reacting to emotional tension, which arises in the social conflict situation, is shaped by the parents' inadequate educational attitude of the emotional distance towards their adolescent child, as well as by the parents' aggressive pattern of reacting to the conflict.
\end{abstract}

Keywords: adolescents, self-esteem, locus of control, emotional reactions, cognitive evaluation, parental attitudes, behavior modeling, aggressive strategy, conflict.

Słowa kluczowe: młodzież, samoocena, poczucie umiejscowienia kontroli, reakcje emocjonalne, ocena poznawcza, postawy rodzicielskie, modelowanie zachowania, strategia agresywnego radzenia sobie, konflikt.

\section{WPROWADZENIE}

Dorośli zazwyczaj nie doceniają, z jak wieloma trudnymi sytuacjami muszą się mierzyć młodzi ludzie. W życiu nastolatków szczególnie częste są trudne sytuacje społeczne, zawierające element zagrożenia realizacji dążeń czy osiagnięcia celu (zaspokojenia potrzeb). Dorastanie jest okresem, w którym młodzież przeżywa różne, często ze sobą sprzeczne dążenia i musi radzić 
sobie z kierowanymi wobec niej niespójnymi oczekiwaniami społecznymi. Każdego dnia młodzi ludzie stoją wobec konieczności rozwiązania różnorodnych problemów dotyczących szkoły, rówieśników i domu rodzinnego. Dotychczasowe rezultaty badań wskazuja, że dorastająca młodzież za źródło silnego pobudzenia emocjonalnego o negatywnym zabarwieniu uznaje konflikty interpersonalne, do których zalicza konflikt z nauczycielem, sprzeczki z kolegami ze szkoły i z sympatią oraz kłótnie z jednym lub obojgiem rodziców i innymi członkami rodziny (Jaworski, 2000; Miłkowska, 2012; Polak, 2010; Różańska-Kowal, 2004).

Najbardziej konfliktowymi obszarami w układzie uczeń-nauczyciel są oceny szkolne, nietaktowne zachowanie nauczyciela oraz władczy nacisk i sztywność wymagań (Miłkowska, 2012). Z kolei główne powody zatargów rówieśniczych to zaczepki, zdrada, niedyskrecja, rywalizacja o stopnie w szkole, o względy u płci przeciwnej, o władzę nad klasą i o prestiż sportowy (Polak, 2010; Różańska-Kowal, 2004). Większość problemów we wzajemnym zrozumieniu rodziców i dzieci wynika ze zmiany stosunku adolescentów do rodziców. Młodzi ludzie są mniej otwarci w stosunku do rodziców, natomiast ci często nie radzą sobie $\mathrm{z}$ coraz większą autonomią dorastających dzieci, starając je ograniczać (Obuchowska, 2010). Wiele konfliktów z rodzicami dotyczy codziennych sytuacji - różnic w gustach i opiniach, na przykład związanych z wynikami w nauce, ubiorem, muzyką, oglądaniem telewizji, korzystaniem z komputera, spędzaniem czasu wolnego czy późnymi powrotami do domu (Jaworski, 2000).

Sytuacja konfliktu z drugim człowiekiem stanowi jedną z podstawowych sytuacji społecznych w życiu każdego człowieka. W kontekście stosunków interpersonalnych sytuacja konfliktowa prezentuje pewien rodzaj interakcji między partnerami, w której wyraźnie uświadamiają sobie dzielące ich różnice interesów, potrzeb czy dążeń do celów (Balawajder, 2010). Sytuacja konfliktu społecznego, która zalicza się do kategorii trudnych sytuacji interakcji społecznych, towarzyszy człowiekowi we wszystkich okresach jego życia. Od chwili narodzin każ- dy musi uczyć się radzić sobie z trudnościami i wyzwaniami, które przed nim stoją. Sytuacja trudna pobudza młodego człowieka do aktywności ukierunkowanej na odzyskanie równowagi między wymaganiami a możliwościami i/lub poprawę stanu emocjonalnego. Aktywność, którą podejmuje on w trudnej sytuacji, rozpatruje się w konkretnym kontekście sytuacyjnym jako strategię radzenia sobie w aktualnej sytuacji trudnej (Wrześniewski, 1996). Zatem strategie radzenia sobie analizowane są zawsze w konkretnej sytuacji trudnej, gdyż od percepcji tej sytuacji w dużej mierze zależą. Warto zwrócić uwagę, jak młodzież radzi sobie z sytuacjami konfliktowymi, które rozgrywają się w szkole, w relacjach z rówieśnikami czy w domu rodzinnym.

Dotychczasowe wyniki badań wskazują, że szczególnie stresujące dla dorastającej młodzieży jest środowisko szkolne, zwłaszcza sytuacje konfliktu z nauczycielami i kolegami ze szkoły. Materiał empiryczny zawarty w literaturze wykazał, że młodzież dysponuje niemałym repertuarem strategii radzenia sobie $\mathrm{z}$ problemami szkolnymi (Miłkowska-Olejniczak, 2002; Woźniak-Krakowian, Wieczorek, 2009). Najczęściej były to zachowania regulujące emocje. Mniej z nich służyło przepracowaniu problemu, analizie i próbie zmiany sytuacji. Wśród wymienionych przez młodych ludzi strategii radzenia sobie w kontekście szkolnych sytuacji trudnych wyróżnić można zachowania agresywne w stosunku do osób i przedmiotów. Lekcje przedmiotowe i przerwy międzylekcyjne są sytuacjami szczególnie sprzyjającymi agresywnym sposobom odreagowania stanu stresu (Miłkowska, 2012; Różańska-Kowal, 2004). W czasie lekcji agresja uczniów polegała m.in. na celowym utrudnianiu nauczycielom prowadzenia zajęć, niszczeniu osobistych przedmiotów pozostawionych na biurku nauczycielskim, wypowiadaniu złych opinii o prowadzącym do kolegów i rodziców. Podczas przerw międzylekcyjnych ponad połowa badanych uczniów przyznała, że podejmuje zachowania agresywne. Dominują przejawy agresji fizycznej (szturchanie, popychanie, kopanie), a wśród form agresji słownej występują przezwiska, wyśmiewanie osoby lub jej rzeczy, drwiny. 
Sytuacje konfliktowe $\mathrm{z}$ rodzicami stanowią w miarę dorastania coraz ważniejsze źródło napięć. Konflikty w relacjach dziecko-rodzic stanowią w okresie adolescencji zjawisko powszechne (Jaworski, 2000). Dzieci w starszym wieku szkolnym (dorastania) pragną się wyzwolić spod kurateli rodziców i całym postępowaniem domagają się przyznania większych niż dotychczas praw. Napotkane przeszkody i niepowodzenia oraz stawiane przez rodziców zakazy i ograniczenia powodują reakcje złości, wyrażające się w aroganckich odpowiedziach, trzaskaniu drzwiami, czasem płaczu lub bezpośrednich atakach agresji skierowanej na przedmioty lub osoby (Lachowska, 2010).

Z dotychczasowych rozważań wynika, że z sytuacją konfliktu społecznego wiąże się problematyka strategii agresywnego radzenia sobie w konkretnym kontekście sytuacyjnym, mającej na celu uniknięcie lub zminimalizowanie napięć, strat i niekorzystnych skutków. Należałoby postawić pytanie: dlaczego młodzież w sytuacji konfliktu społecznego wybiera strategię agresji? W odpowiedzi na to pytanie pomocna jest koncepcja psychologicznego mechanizmu zachowania się człowieka w sytuacjach trudnych w opracowaniu Marii Tyszkowej (1986). Istotna rolę odgrywaja, według tej autorki, schematy poznawcze, wyznaczające procesy percypowania sytuacji zewnętrznej, emocjonalne odzwierciedlenie przez podmiot znaczenia tej sytuacji i przebiegu własnych działań oraz ukształtowany w określonych warunkach wychowawczych zespół nawyków reagowania na napięcie emocjonalne, jaki w danej sytuacji powstaje.

Aktywność człowieka w sytuacji trudnej zależy w dużej mierze od dokonania przez niego oceny położenia, w jakim się znalazł. Sytuacja trudna, która zakłóca dotychczasowy tok czynności, utrudnia, zagraża bądź uniemożliwia człowiekowi realizację potrzeb, może zostać oceniona jako krzywda/strata (dotyczy poniesionych szkód i strat związanych z ważnymi obiektami i przedmiotami), zagrożenie (odnosi się do podobnych szkód, które jeszcze nie wystapiły i są antycypowane) i wyzwanie (wskazuje na możliwość opanowania sytuacji trudnej i zyskania czegoś) (Włodarczyk, 1999; Włodarczyk, Wrześniewski, 2005). Indywi- dualna ocena wydarzenia wpływa na decyzje jednostki dotyczące możliwości podjęcia działania usuwających przyczyny sytuacji trudnej lub przynajmniej łagodzących jej skutki, określanego jako strategia zaradcza (Heszen-Niejodek, 2000; Scherer, Coleman, Drumheller, Owen, 1994; Winstok, 2007). Zatem czynnikiem warunkującym wybór strategii radzenia sobie w trudnych sytuacjach społecznych jest interpretacja zaistniałej sytuacji, czyli realizowana przez jednostkę ocena poznawcza. $Z$ danych uzyskanych przez Louisa Chandlera (1986) i Dorotę Domińską-Werbel (2014) wynika, że młodzież dorastająca wykorzystująca strategie agresywnego radzenia sobie w trudnych sytuacjach społecznych charakteryzuje się wyższym nasileniem sytuacyjnej i dyspozycyjnej oceny poznawczej sytuacji trudnej jako krzywda/strata. Z kolei Elżbieta Pawłów (1997) ustaliła, że osoby badane oceniające sytuację trudną jako zagrożenie w kontakcie z problemem posługiwały się w znacznej mierze emocjonalnymi mechanizmami radzenia sobie. Cały ich wysiłek został skierowany w stronę obniżenia przykrego napięcia na skutek gwałtownego wyładowania i/lub zaktywizowania mechanizmów obronnych, nie zaś $\mathrm{w}$ stronę rzeczywistego rozwiązania problemu. Zatem osoby reprezentujące wyższe nasilenie sytuacyjnej i dyspozycyjnej oceny poznawczej sytuacji trudnej jako krzywda/strata lub jako zagrożenie w zachowaniu ujawniają agresję, nadaktywność czy bunt.

To, jak człowiek postrzega świat, jakie są jego postawy i oczekiwania w stosunku do samego siebie, do innych ludzi, do zadań i rezultatów własnej aktywności, określa sposób poznawczego i emocjonalnego percypowania i interpretowania sytuacji trudnej. Zespół pojęć i wyobrażeń o sobie oraz oczekiwań w stosunku do siebie, jakim jest struktura ja, odgrywa znaczącą rolę w zachowaniu się człowieka w sytuacjach trudnych (Kulas, 1986). Informacje dotyczące własnej osoby, cechy składające się na wiedzę o samym sobie stanowią przesłankę do oceny własnych możliwości w sytuacjach trudnych. Z tego, co wiemy, samoocena stanowi oceniająco-wartościujący komponent struktury ja. Jej wpływ uwidacznia się w funkcjonowaniu jednostki w sytuacjach trudnych. Jak się okazu- 
je, niekorzystna, niedostatecznie zorganizowana i nietrafna struktura ja ulega w trudnej sytuacji zagrożeniu, co powoduje przesuwanie się celu aktywności w kierunku obrony własnego ja jednostki (Tyszkowa, 1986). Rezultatem jest dezorganizacja czynności ukierunkowanej na cel. Niekorzystną rolę w zachowaniu młodego człowieka w sytuacjach trudnych odgrywa niska (adekwatna, nieadekwatna) lub wysoka (nieadekwatna) samoocena (Borecka-Biernat, 2006; Kubacka-Jasiecka, 1986; Ogińska-Bulik, 2001; Ostrowsky, 2010; Turner, White, 2015; Tyszkowa, 1997; Rostowska, 2001). W zetknięciu jednostki z trudnościami sytuacji nieadekwatna samoocena prowadzi do wzrostu poczucia osobistego zagrożenia, rozrostu emocji negatywnych i postępującej dezorganizacji zachowania. Niska ocena siebie, własnych możliwości i skuteczności działania w obliczu różnych trudnych wydarzeń sprzyja pojawieniu się zachowań agresywnych. Podobnie w wypadku samooceny wysokiej (nieadekwatnej) obserwujemy tendencję do wyładowczych reakcji agresywnych. Jak widać, samoocena niska lub wysoka (nieadekwatna) obniża odporność psychiczną na sytuacje trudne, zmniejsza efektywność działania i utrudnia adaptację czy radzenie sobie jednostki w sytuacji trudnej. Niewielka nawet przeszkoda bądź nikłe zagrożenie może u osób o niskiej lub wysokiej (nieadekwatnej) samoocenie wywołać niepohamowaną agresję.

O funkcjonowaniu jednostki w sytuacjach trudnych decyduje subiektywne przekonanie dotyczące możliwości sprawowania jej kontroli nad sytuacją (Tyszkowa, 1978). Człowiek działa w sytuacjach, w których spotykające go powodzenia i niepowodzenia traktuje jako następstwo sił będących poza zasięgiem osobistej kontroli - mówimy wtedy o ,poczuciu zewnętrznej kontroli” - czy też rezultat działań zależy od jego własnego zachowania i umiejętności i wówczas określa się to jako, ,poczucie wewnętrznej kontroli” (Drwal, 1978). Ludzie różnią się sposobem widzenia sytuacji, w której przyszło im działać. Jedni mają tendencję do postrzegania większości sytuacji jako takich, w których widzą duży wpływ czynników niekontrolowanych na wyniki swej działalności i tym samym spostrzegają siebie jako ,nie- panujących nad sytuacją". Inni zaś mają tendencję do spostrzegania sytuacji jako takich, w których wyniki ich działalności zależą od nich samych, a tym samym spostrzegają siebie jako ,panujących nad sytuacją" (Drwal, 1978; Rotter, Chance, Phares, 1972). Oznacza to, że subiektywne przekonania jednostki dotyczące jej kontroli nad otaczającym światem są ważną zmienną regulująca przebieg procesu radzenia sobie sytuacji trudnej i wpływającą na podejmowane strategie zaradcze (Halloran, Doumas, John, Margolin, 1999; Krause, Stryker, 1984; Kurtek, 2005). Z badań przeprowadzonych przez Danutę Borecką-Biernat (2006), Marię Gacek (2000) i Pawła Kurtka (2005) wynika, iż osoby charakteryzujące się brakiem przeświadczenia o możliwości wpływania na pozytywne rezultaty własnych działań wykazują skłonność do agresji. Także Teresa Rostowska (2001) ustaliła, że konfliktowe relacje młodych ludzi z innymi (np. wzajemna niechęć, nieżyczliwość, obwinianie się) to formy zachowania współwystępujące najczęściej z poczuciem zewnętrznej kontroli. Stąd też te osoby cechowały się większą podatnością na zachowania konfliktowe. Jak widać, ocena sytuacji, co do której człowiek nie jest przekonany, że ma nad nią kontrolę, jest związana $\mathrm{z}$ agresywną formą radzenia się problemami.

Sytuacja konfliktowa, która stanowi immanentny element interakcji społecznych, wywołuje silne napięcie emocjonalne o negatywnym zabarwieniu. Utrzymujące się pobudzenie emocjonalne o dużym nasileniu i zabarwieniu negatywnym stanowi podstawę do zachowań agresywnych, irytacji i wybuchów wściekłości (Gross, Halperin, Porat, 2013; Terelak, 2001). Rodzajem emocji, które prowadzą do zachowań agresywnych, są te zgodne z sekwencją: irytacja-złość-gniew. Ich natężenie określa nasilenie i formę agresji. Jak zauważa Władysław Łosiak (2009), emocje złości i gniewu są pokrewnymi stanami emocjonalnymi, które łączy podobieństwo na poziomie subiektywnego przeżywania, a także powiązanie $\mathrm{z}$ zachowaniami agresywnymi. Warto zauważyć, że gniew i złość są jedną z możliwych reakcji emocjonalnych o znaku ujemnym, która się pojawia podczas doświadczania sytuacji stresowej, postrzeganej jako zagrożenie lub strata/krzywda (Lazarus, 
1986). Zdaniem Leonarda Berkowitza (1992) i Zbigniewa Skornego (1987) emocje gniewu i złości uruchamiają działania ukierunkowane na odzyskanie zagrożonych lub utraconych celów działania i prowadzą do zachowań agresywnych. Także Joanna Różańska-Kowal (2004) w rezultacie przeprowadzonych badań stwierdza, że skłonność do reagowania złością jest powiązana z podejmowaniem walki, niepoddawaniem się w sytuacjach trudnych.

Z kolei emocje w sekwencji: niepokójlęk-strach na ogół prowadzą do wycofania się, ucieczki (Borecka-Biernat, 2006; Borecka-Biernat, Ciuladiene, 2015; Łosiak, 2009). Wydaje się, że w warunkach naturalnych gniew jest emocją facylitujacą czynności walki, natomiast strach facylituje czynność ucieczki. Jednakże obserwacje wykazuja, że kiedy człowiek nie ma gdzie uciekać, kiedy nie ma już żadnej możliwości poza samą agresją albo atakowaniem, wtedy lęk może być powodem ataku. Na współwystępowanie reakcji lęk-agresja zwracają uwagę Antoni Kępiński (1992) oraz Jeno Ranschurg (1993). Agresja stanowi zatem skuteczną formę radzenia sobie $\mathrm{z}$ lękiem odczuwanym $\mathrm{w}$ sytuacjach społecznych. Reakcja ta pomaga rozładować napięcie lękowe lub ukryć lęk (Eysenck, 2001; Nitendel-Bujakowa, 2001).

Strategia agresywnego radzenia sobie ze społeczną sytuacją trudną stanowi formę zachowania nabytą zgodnie z ogólnymi zasadami uczenia się. Sposoby ujmowania przeszkody i zachowania w społecznych sytuacjach trudnych, do których zalicza się konflikt, zależą w znacznej mierze od wytworzonych w procesie wychowania nawyków reagowania na trudności. Układ postaw emocjonalnych między rodzicami a dzieckiem ma doniosły wpływ na jego rozwój społeczny; staje się dla niego prototypem współżycia społecznego i rozwiązywania społecznych sytuacji trudnych (Tyszkowa, 1986). W literaturze przedmiotu (Guszkowska, 2004; Januszewska, 2001; Liberska, Matuszewska, Freudenreich, 2013; Łukaszewicz, 2002; Poraj, 2002; Wolińska, 2000) znajdujemy dane poświadczające, że agresywne formy reagowania dziecka na społeczne sytuacje trudne sa konsekwencją nieprawidłowych postaw wychowawczych, które sprowadzają się do: 1. po- stawy nadmiernego dystansu, 2. nadmiernych wymagań, 3. nadmiernego ochraniania oraz 4. niekonsekwencji. Nieprawidłowe postępowanie rodziców powoduje niezaspokojenie znaczących potrzeb dziecka, a w szczególności potrzeby bliskiego kontaktu uczuciowego, klimatu miłości rodzicielskiej i poczucia bezpieczeństwa. Uważa się, że osoba z poczuciem braku bezpieczeństwa społecznego, znajdując się w stanie zagrożenia i niepokoju związanego ze sferą kontaktów interpersonalnych, uruchamia strategię agresywnego radzenia sobie z sytuacją trudną, mającą na celu ochronę przeciążonego systemu regulacji.

W wielu sytuacjach trudnych zachowanie człowieka zależy nie tylko od cech samej sytuacji, na którą ma on zareagować, lecz także od sposobu zachowania się innych ludzi znajdujących się w tej samej sytuacji. Środowiskiem stwarzającym naturalne warunki sprzyjające uczeniu się sposobów reagowania w odpowiedzi na sytuacje trudne jest rodzina, a rodzice są dla dziecka pierwszymi modelami określonych strategii radzenia sobie $\mathrm{z}$ trudnościami. Główne wzory reagowania na trudności dziecko znajduje w zachowaniu rodziców w sytuacjach napięć emocjonalnych oraz w ich ustosunkowaniu się do trudności i niepowodzeń dziecka w działaniu (Tyszkowa, 1986). Badania dowiodły, że większość dzieci ujawniających agresywne strategie radzenia pochodzi z rodzin, gdzie jedno lub oboje rodziców to osoby agresywne (Borecka-Biernat, 2006; Rostowska, 2001; Wolińska, 2013). Agresywne formy zachowań w konfliktach dziecięcych są przełożeniem konfliktów rodzinnych, które stanowią dla dzieci negatywny wzorzec w tym względzie. W rodzinach skłóconych częste awantury, ostre zwroty, sceny bójek, niszczenie lub rzucanie przedmiotami oraz trzaskanie drzwiami dziecko przyjmuje jako swoje, stosuje je nie tylko w kontaktach z rodzicami, rodzeństwem, lecz także przenosi je na teren szkoły, arogancko zachowuje się wobec nauczycieli, jest agresywne w kontaktach rówieśniczych, uczy się rozwiązywać konflikty przy użyciu siły, zwłaszcza gdy obserwuje korzystny rezultat agresywnego zachowania (Narayan, Chen, Martinez, Gold, Klimes-Dougan, 2015; Obuchowska, 2001; Patterson, 1986; Urban, 
2005). Należy sądzić, że odbywa się transmisja zachowań agresywnych, gdy dziecko przyjmuje ze środowiska rodzinnego agresywne formy zachowań i traktuje je jako skuteczne sposoby radzenia sobie z sytuacją konfliktu społecznego.

Reasumując: koncepcja psychologicznego mechanizmu zachowania człowieka w sytuacjach trudnych, przedstawiona przez M. Tyszkową (1986), pozwala na opisanie niektórych osobowościowych i rodzinnych uwarunkowań strategii agresji, stosowanej przez młodzież w sytuacji konfliktu społecznego. Mimo to w uwarunkowaniach tych należy poszukać determinant stosowanej przez młodzież strategii agresywnego radzenia sobie z sytuacją konfliktu społecznego.

\section{PROBLEM I HIPOTEZA BADAWCZA}

Badania empiryczne skupiono wokół osobowościowych i rodzinnych predyktorów strategii agresywnego radzenia sobie młodzieży w sytuacji konfliktu społecznego, ze szczególnym zwróceniem uwagi na rolę rodzaju oceny poznawczej sytuacji konfliktu społecznego, poziomu samooceny, poczucia umiejscowienia kontroli, poziomu i treści emocji oraz postaw wychowawczych rodziców i wzoru reagowania rodziców na sytuację konfliktu społecznego. Zmierzały one do odpowiedzi na następujące pytanie badawcze: Jaki zespół zmiennych osobowościowych i rodzinnych ma związek z faktem, że w trakcie sytuacji konfliktu społecznego nasila się stosowanie strategii agresji wśród młodzieży?

Tak sformułowane pytanie badawcze pozwala na postawienie następującej hipotezy, której weryfikacji posłuży analiza wyników przeprowadzonych badań empirycznych:

H.1. Strategia agresywnego radzenia sobie młodzieży w sytuacji konfliktu społecznego wiąże się z oceną sytuacji konfliktu jako zagrożenia lub jako krzywdy/straty, z niskim lub wysokim poziomem samooceny ogólnej, zewnętrznym poczuciem kontroli, wysokim poziomem emocji negatywnych (gniew, lęk) i z percepcją postaw rodzicielskich jako nieprawidłowych oraz prezentowanym modelem strategii agresywnego radzenia sobie przez rodziców (jednego lub obojga) w sytuacji konfliktu społecznego.

\section{METODA}

\section{Osoby badane i przebieg badań}

Przebadano grupę 468 dziewcząt i 425 chłopców w wieku trzynastu-piętnastu lat. Ogółem W przeprowadzonych analizach wzięło udział 893 osób. Badani byli uczniami pierwszych, drugich i trzecich klas gimnazjalnych. Zastosowano wybór losowy szkół, jednak nie wszystkie wylosowane szkoły zgodziły się na przeprowadzenie w nich badań, dlatego też w kilku przypadkach zwrócono się do szkół niewylosowanych, z którymi tego rodzaju współpraca była możliwa. Badania były prowadzone w trakcie czterech spotkań (było to uwarunkowane czasem, który poświęca się na każdą z metod). Badania uczniów przeprowadzono najczęściej na lekcjach wychowawczych. Miały charakter grupowy, a udział w nich był dobrowolny. Uczniowie podpisywali się pseudonimami lub inicjałami. Przed przystąpieniem do badania gimnazjalistom udzielano wskazówek i wyjaśnień oraz zapewniono jednolitość instrukcji.

Podstawowym kryterium doboru badanych uczniów był wiek. Jego wpływ na dobór strategii agresji radzenia sobie w sytuacji konfliktu społecznego analizowano w grupie trzynaściepiętnaście lat (podokres wczesnej adolescencji). Wiek dorastania jest ważnym etapem w życiu każdego człowieka, ponieważ jest uważany za moment przejściowy między dzieciństwem a dorosłością. Określany jest też jako okres buntu i naporu. W nim dokonuje się wiele zmian biologicznych, psychicznych, mentalnych, motywacyjnych i w postawach społecznych, które sprawiają że młodzież ma niejednokrotnie wiele problemów z dostosowaniem swojego postępowania do nowych sytuacji, zadań i ról społecznych (Czerwińska-Jasiewicz, 2003; Harwas-Napierała, Trempała, 2000; Jackson, Bistra, Oostra i Bosma, 1998). Ze względu na rozwój krytycznej oceny otaczającej rzeczywistości i wzmożone kształtowanie się obrazu własnej osoby, supremację sfery uczuciowej nad inny- 
mi dziedzinami życia psychicznego oraz nowe formy kontaktów społecznych i bezpośredniość w zachowaniu, młodzież w wieku trzynastupiętnastu lat wydaje się dobrym przedmiotem badań do poznania strategii agresywnego radzenia sobie w sytuacji silnego napięcia emocjonalnego, jaką jest konflikt społeczny.

\section{Narzędzia badawcze}

W badaniach posłużono się Kwestionariuszem Oceny Stresu (KOS) Doroty Włodarczyk i Kazimierza Wrześniewskiego (2010), Skalą Samooceny (SES) Morrisa Rosenberga w adaptacji Marioli Łaguny, Kingi Lachowicz-Tabaczek i Ireny Dzwonkowskiej (2007), Kwestionariuszem do Badania Poczucia Kontroli (KBPK) Grażyny Krasowicz i Anny Kurzyp-Wojnarskiej (1990), Trójczynnikowym Inwentarzem Stanów i Cech Osobowości (TISCO) Charlesa Spielbergera i Kazimierza Wrześniewskiego (Wrześniewski, 1991), Skalą Postaw Rodzicielskich (SPR) Mieczysława Plopy (2007), Skalą (,A”) Agresywnego Radzenia Sobie Matki/Ojca w Sytuacji Konfliktu Społecznego z Kwestionariusza do Badania Strategii Radzenia Ssobie Rodziców w Sytuacji Konfliktu Społecznego w percepcji dziecka (SRwSK) Danuty Boreckiej-Biernat (2013) i Skalą (,A”) Agresywnego Radzenia Sobie Młodzieży w Sytuacji Konfliktu Społecznego z Kwestionariusza do Badania Strategii Radzenia Sobie Młodzieży w Sytuacji Konfliktu Społecznego (KSMK) Danuty Boreckiej-Biernat (2012).

1. Kwestionariusz Oceny Stresu (KOS) opracowany przez D. Włodarczyk i K. Wrześniewskiego (2010) zawiera 35 (w tym 23 diagnostycznych) przymiotnikowych określeń oceniających sytuacje stresowe. Składa się z dwóch wersji, które obejmują te same zestawy przymiotnikowych określeń, a różnią się instrukcją podawaną osobom badanym. W wersji A (pomiar sytuacyjnej oceny stresu) osoby badane proszone są o wskazanie konkretnej sytuacji trudnej, która wydarzyła się w ciagu ostatniego tygodnia (w opisywanym badaniu była to sytuacja konfliktu społecznego). Wersja B (pomiar dyspozycyjnej oceny stresu) za- wiera instrukcję, w której osoby badane proszone są o zaznaczenie, w jakim stopniu podane przymiotniki są zgodne z tym, czego najczęściej doświadczają w sytuacjach trudnych (w opisywanym badaniu była to sytuacja konfliktu społecznego). KOS składa się z sześciu podskal, będących wskaźnikami poszczególnych rodzajów oceny stresu. Są to: zagrożenie-stan, zagrożenie-cecha, krzywda/strata-stan, krzywda/strata-cecha, wyzwanie-stan i wyzwanie-cecha. Podskale ,zagrożenia” zawierają dziesięć pozycji, podskale „wyzwanie” - sześć pozycji, a „krzywda/strata” - cztery pozycje.

2. Skala Samooceny (SES) M. Rosenberga w adaptacji M. Laguny, K. Lachowicz-Tabaczek i I. Dzwonkowskiej (2007) daje możliwość obliczenia poziomu ogólnej (globalnej) samooceny zarówno u młodzieży, jak i osób dorosłych. SES składa się z dziesięciu diagnostycznych twierdzeń opisowych dotyczących własnej osoby, za pomocą których badany dokonuje opisu samooceny swojego ja. Wysoki wynik oznacza wysoki poziom ogólnej (globalnej) samooceny.

3. Kwestionariusz do Badania Poczucia Kontroli (KBPK) G. Krasowicz i A. Kurzyp-Wojnarskiej (1990) służy do pomiaru zmiennej osobowościowej, zwanej poczuciem umiejscowienia kontroli. Składa się z 46 pytań (w tym 36 diagnostycznych) dotyczących prostych sytuacji z życia młodzieży. Tworzą one dwie skale: skalę sukcesów (S) i skalę porażek (P). Suma wyników uzyskanych w skalach sukcesów i porażek tworzy wskaźnik zgeneralizowanego poczucia umiejscowienia kontroli $(\mathrm{S}+\mathrm{P})$. Wysokie wyniki świadczą o wewnętrznej kontroli następstw zdarzeń, zaś niskie o zewnętrznej kontroli następstw zdarzeń.

4. Trójczynnikowy Inwentarz Stanów i Cech Osobowości (TISCO) jest polską adaptacją amerykańskiego testu State-Trait Personality Inventory (STPI) opracowanego przez zespół C. Spielbergera (Wrześniewski, 1991). TISCO składa się z dwóch niezależnych części. Część pierwsza (SPI) jest przeznaczona do pomiaru lęku, gniewu i ciekawości, traktowanych jako stany emocjonalne od- 
czuwane w danym momencie. Część druga (TPI) używana jest do badania tych samych emocji traktowanych jako cechy osobowości. Test zawiera zatem sześć podskal: lęk jako stan i lęk jako cecha, gniew jako stan i gniew jako cecha oraz ciekawość jako stan i ciekawość jako cecha. Każda z podskal składa się z dziesięciu krótkich, prostych stwierdzeń, odnoszących się do subiektywnych odczuć jednostki.

5. Skala Postaw Rodzicielskich (SPR) M. Plopy (2007) służy do badania postaw rodzicielskich w percepcji dzieci. Obejmuje 75 stwierdzeń w wersji dla matki i w wersji dla ojca. Kwestionariusz składa się z pięciu skal, każda zaś zawiera po 15 stwierdzeń. Są to: Postawa Akceptacji - Odrzucenie (I), Postawa Autonomii (II), Postawa Nadmiernie Ochraniająca (III), Postawa Nadmiernie Wymagająca (IV), Postawa Niekonsekwentna (V).

6. Kwestionariusz Strategii Radzenia Sobie Rodziców w Sytuacji Konfliktu Społecznego (SRwSK) D. Boreckiej-Biernat (2013) składa się z dwóch wersji, Moja Matka i Mój Ojciec. Przeznaczony jest do badania strategii radzenia sobie rodziców w sytuacji konfliktu społecznego, przy czym zachowania te poznawane są w percepcji ich dorastających dzieci. Narzędzie posiada opisy 16 sytuacji konfliktu społecznego w wersji Moja Matka i taką samą liczbę opisów w wersji Mój Ojciec. Do każdej z sytuacji podano cztery zachowania wyrażające radzenie sobie rodziców w sytuacji konfliktu społecznego w percepcji ich dziecka; pierwsze odnosi się do agresywnego radzenia (,A”), drugie do unikowego radzenia (,U”), trzecie do uległego radzenia („Ul”), a czwarte do zadaniowego radzenia sobie w sytuacji konfliktu społecznego. Każdej z czterech możliwych odpowiedzi przyporządkowano wartość liczbową od 0 do 1 . Suma punktów stanowiła wskaźnik liczbowy określający stopień natężenia każdej z tych strategii. Im wyższa wartość liczbowa wskaźnika, w tym większym stopniu dziecko spostrzega rodziców jako stosujących daną strategię. Na potrzeby badań własnych wykorzystano Skalę (,A”)
Agresywnego Radzenia Sobie Matki/Ojca w Sytuacji Konfliktu Społecznego.

7. Kwestionariusz Strategii radzenia sobie Młodzieży w sytuacji Konfliktu społecznego (KSMK) opracowany przez D. Borecką-Biernat (2012) przeznaczony jest do badania strategii radzenia w sytuacji konfliktu społecznego podejmowanej przez młodzież w wieku dorastania. Składa się z opisu 33 sytuacji konfliktu społecznego. Do każdej sytuacji podano cztery zachowania wyrażające radzenie sobie z sytuacją konfliktu społecznego -pierwsze odnosi się do agresywnego radzenia (,A”), drugie do unikowego („U”), trzecie do uległego (,Ul”), a czwarte do zadaniowego radzenia sobie w sytuacji konfliktu społecznego (,Z”). Wyniki uzyskuje się dla każdej skali oddzielnie, poprzez sumowanie zaznaczonych zachowań w 33 sytuacjach należących do danej skali. Na potrzeby badań własnych wykorzystano Skalę (,A”) Agresywnego Radzenia Sobie Młodzieży w Sytuacji Konfliktu Społecznego.

\section{WYNIKI}

W celu ustalenia związków między badanymi zmiennymi niezależnymi (objaśniającymi) a zmienną zależną (wyjaśnianą) i wyznaczenia predyktorów strategii agresywnego radzenia w sytuacji konfliktu społecznego u młodzieży, przeprowadzono wielokrotną analizę regresji (według procedury krokowej). Za zmienną zależną przyjęto wyniki w skali „A” Kwestionariusza Strategii Radzenia Sobie Młodzieży w Sytuacji Konfliktu Społecznego (KSMK). Jako zbiór zmiennych niezależnych potraktowano wyniki w sześciu skalach (Zagrożenie-stan i Zagrożenie-cecha, Krzywda/Strata-stan i Krzywda/Strata-cecha, Wyzwanie-stan i Wyzwanie-cecha) Kwestionariusza Oceny Stresu (KOS), w jednej skali (Samoocena) kwestionariusza Skala Samooceny (SES), w dwóch skalach (Sukces i Porażka) Kwestionariusza do Badania Poczucia Kontroli (KBPK), w sześciu skalach (Gniew-stan i Gniew-cecha, Lęk-stan i Lęk-cecha oraz Ciekawość-stan i Ciekawość-cecha) Trójczynnikowego Inwentarza Stanów 
i Cech Osobowości (TISCO), w pięciu skalach (Postawa Akceptacji-Odrzucenia, Postawa Autonomii, Postawa Ochraniająca, Postawa Wymagająca, Postawa Niekonsekwencji) kwestionariusza Skala Postaw Rodzicielskich (SPR) w wersji Moja Matka i Mój Ojciec oraz w jednej skali (Agresywne Radzenie Sobie w Sytuacji Konfliktu Społecznego [,A”]) Kwestionariusza Strategii Radzenia Sobie Rodziców w Sytuacji Konfliktu Społecznego (SRwSK) w wersji Moja Matka i Mój Ojciec. Wykonano analizę na wynikach całej grupy oraz przeprowadzono odrębne analizy dla grup wydzielonych ze względu na płeć. Wyniki przedstawiono w tabeli 1.

Pierwszą analizę wykonano na wynikach całej grupy badanej młodzieży, bez względu na płeć. Jak widać w tabeli 1, osiem zmiennych niezależnych miało istotny wpływ na strategię agresywnego radzenia sobie młodzieży w sytuacji konfliktu społecznego: zagrożenie-stan, poczucie umiejscowienia kontroli w sytuacji sukcesów, gniew jako aktualny stan emocjonalny, gniew jako cecha osobowości i lęk ujmowany jako cecha osobowości oraz postawa akceptacji-odrzucenia matki i strategia agresji matki i ojca stosowana w sytuacji konfliktu społecznego. Wyjaśniały one $36 \%$ zmienności wyników na skali strategii agresywnego radzenia sobie młodzieży w sytuacji konfliktu społecznego. Pozostałe zmienne uwzględnione w badaniu okazały się nieistotnymi wyznacznikami strategii agresji w grupie młodzieży. Wartości beta wskazuja, że im wyższy poziom sytuacyjnej oceny konfliktu jako zagrożenia, im silniejsze przekonanie o zewnętrznym poczuciu umiejscowienia kontroli dla sytuacji sukcesów, im wyższy poziom gniewu rozumiany jako chwilowy stan emocjonalny przeżywany w związku z sytuacją konfliktu społecznego i im wyższy poziom wyuczonej dyspozycji do reagowania gniewem, jak i im niższy poziom dyspozycji do reakcji lękowych oraz im wyższy poziom postawy matki nasyconej chłodem uczuciowym, dezaprobatą, wrogością, odtrąceniem wobec dziecka i im wyższe poziomy strategii agresywnego radzenia sobie matki i ojca stosowanej w sytuacji konfliktu społecznego, tym wyższy poziom strategii agresywnego radzenia sobie dorastających w sytuacji konfliktu społecznego.
Przeprowadzono odrębne analizy dla grup wydzielonych ze względu na płeć (por. tabela 1). Krokowa analiza regresji wykazała, że spośród 27 zmiennych niezależnych wprowadzonych do modelu regresji, dziewięć miało istotne znaczenie w wyjaśnianiu strategii agresywnego radzenia sobie stosowanej przez dziewczęta w sytuacji konfliktu społecznego. Pozostałe zmienne uwzględnione w badaniu okazały się nieistotnymi wyznacznikami strategii agresji u dziewcząt. Z obliczeń wynika, iż ważną rolę determinującą dla strategii agresywnego radzenia sobie przez dziewczęta odgrywają: zagrożenie-stan, samoocena, poczucie umiejscowienia kontroli w sytuacji sukcesów i w sytuacji porażek, gniew jako chwilowy stan odczuwany w związku z sytuacją konfliktu społecznego i lęk jako aktualny stan emocjonalny przeżywany w sytuacji konfliktu społecznego oraz postawa akceptacji-odrzucenia matki i strategia agresji matki i ojca stosowana w sytuacji konfliktu społecznego. Współczynnik determinacji wielokrotnej ukazuje, że 43\% wariancji zmiennej zależnej jest wyjaśniona przez te zmienne. Parametry równania regresyjnego, w tym jego istotność, świadcząjednak o tym, że im wyższy poziom oceny sytuacji związanej z konfliktem jako zagrożeniem, im wyższy poziom samooceny, im silniejsze przekonanie o zewnętrznym poczuciu umiejscowienia kontroli odrębnie dla sytuacji sukcesów i sytuacji porażek, im wyższy poziom gniewu o charakterze sytuacyjnym i im niższy poziom lęku rozumiany jako chwilowy stan emocjonalny przeżywany w związku z sytuacją konfliktu społecznego oraz im wyższy poziom postawy matki nasyconej chłodem uczuciowym, dezaprobata, wrogością, odtrąceniem wobec córki i im wyższe poziomy strategii agresywnego radzenia sobie matki i ojca stosowanej w sytuacji konfliktu społecznego, tym wyższy poziom strategii agresywnego radzenia sobie w sytuacji konfliktu społecznego przez dziewczęta.

Sprawdzono też, jaki zespół zmiennych osobowościowych i rodzinnych ma wpływ na poziom strategii agresywnego radzenia sobie chłopców w sytuacji konfliktu społecznego. Pięć zmiennych niezależnych okazało się istotnych w równaniu regresyjnym. Są nimi: poczucie 
Tabela 1. Krokowa regresja wielokrotna dla wyniku skali Agresja („A”) Kwestionariusza Strategii Radzenia Sobie Młodzieży w Sytuacji Konfliktu Społecznego (KSMK) względem wyników skal: Kwestionariusza Oceny Stresu (KOS) Skali Samooceny (SES), Kwestionariusza do Badania Poczucia Kontroli (KBPK), Trójczynnikowego Inwentarza Stanów i Cech Osobowości (TISCO), Skali Postaw Rodzicielskich (SPR) i Skali „A” z Kwestionariusza Strategii Radzenia Sobie Rodziców w Sytuacji Konfliktu Społecznego (SRwSK): wyniki dla całej grupy $(N=893)$ oraz dla dziewcząt $(N=468)$ i chłopców $(N=425)$

\begin{tabular}{|c|c|c|c|c|c|c|}
\hline Osoby badane & Zmienna & Beta & $B$ & Błąd st. B & $t$ & $\begin{array}{c}\text { Poziom } \\
p<\end{array}$ \\
\hline Ogółem & $\begin{array}{l}\text { Zagrożenie-stan } \\
\text { Sukces } \\
\text { Gniew-stan } \\
\text { Gniew-cecha } \\
\text { Lęk-cecha } \\
\text { A-O Matka } \\
\text { "A" Matka } \\
\text { "A" Ojciec } \\
\text { W. wolny }\end{array}$ & $\begin{array}{c}.07 \\
-.16 \\
.09 \\
.18 \\
-.13 \\
-.12 \\
.34 \\
.11\end{array}$ & $\begin{array}{c}.06 \\
-.23 \\
.06 \\
.13 \\
-.12 \\
-.05 \\
.69 \\
.22 \\
6.60\end{array}$ & $\begin{array}{l}.02 \\
.04 \\
.02 \\
.03 \\
.03 \\
.02 \\
.06 \\
.06 \\
1.17\end{array}$ & $\begin{array}{c}2.64 \\
-5.44 \\
2.88 \\
5.17 \\
-3.85 \\
-4.19 \\
11.32 \\
3.78 \\
5.63\end{array}$ & $\begin{aligned} & .008 \\
&< .001 \\
& .004 \\
&<.001 \\
&<.001 \\
&<.001 \\
&<.001 \\
&<.001 \\
&<.001\end{aligned}$ \\
\hline \multicolumn{7}{|c|}{$\begin{array}{l}\text { Współczynnik korelacji wielokrotnej: } R=.60 \\
\text { Współczynnik wielokrotnej determinacji: } R^{2}=.36 \\
\text { Istotność równania: } F(8,884)=60.78 ; p<.00001 \\
\text { Błąd std. estymacji: } 3.75\end{array}$} \\
\hline Dziewczęta & $\begin{array}{l}\text { Zagrożenie-stan } \\
\text { Samoocena } \\
\text { Sukces } \\
\text { Porażka } \\
\text { Gniew-stan } \\
\text { Lęk-stan } \\
\text { A-O Matka } \\
\text { "A" Matka } \\
\text { „A" Ojciec } \\
\text { W. wolny }\end{array}$ & $\begin{array}{l}.10 \\
.10 \\
-.11 \\
-.10 \\
.19 \\
-.16 \\
-.08 \\
.43 \\
.11\end{array}$ & $\begin{array}{c}.08 \\
.10 \\
-.16 \\
-.15 \\
.14 \\
-.21 \\
-.03 \\
.82 \\
.22 \\
6.18\end{array}$ & $\begin{array}{l}.03 \\
.04 \\
.06 \\
.06 \\
.03 \\
.06 \\
.02 \\
.08 \\
.08 \\
1.96\end{array}$ & $\begin{array}{c}2.85 \\
2.79 \\
-2.49 \\
-2.31 \\
4.18 \\
-3.48 \\
-2.17 \\
10.84 \\
2.89 \\
3.15\end{array}$ & $\begin{array}{c}.005 \\
.006 \\
.010 \\
.020 \\
<.001 \\
<.001 \\
.030 \\
<.001 \\
.004 \\
.002\end{array}$ \\
\hline \multicolumn{7}{|c|}{$\begin{array}{l}\text { Współczynnik korelacji wielokrotnej: } R=.66 \\
\text { Współczynnik wielokrotnej determinacji: } R^{2}=.43 \\
\text { Istotność równania: } F(9,458)=38.31 ; p<.00001 \\
\text { Błąd std. estymacji: } 3.54\end{array}$} \\
\hline Chłopcy & $\begin{array}{l}\text { Sukces } \\
\text { Gniew-cecha } \\
\text { A-O Matka } \\
\text { „A" Matka } \\
\text { „A" Ojciec } \\
\text { W. wolny }\end{array}$ & $\begin{array}{l}-.15 \\
.19 \\
-.17 \\
.26 \\
.11\end{array}$ & $\begin{array}{c}-.22 \\
.14 \\
-.07 \\
.57 \\
.21 \\
7.44\end{array}$ & $\begin{array}{l}.07 \\
.03 \\
.02 \\
.10 \\
.09 \\
1.59\end{array}$ & $\begin{array}{c}-3.40 \\
4.27 \\
-3.84 \\
5.74 \\
2.32 \\
4.68\end{array}$ & $\begin{aligned}<.001 \\
<.001 \\
<.001 \\
<.001 \\
\quad .020 \\
<.001\end{aligned}$ \\
\hline \multicolumn{7}{|c|}{$\begin{array}{l}\text { Współczynnik korelacji wielokrotnej: } R=.54 \\
\text { Współczynnik wielokrotnej determinacji: } R^{2}=.30 \\
\text { Istotność równania: } F(5,419)=35.18 ; p<0.00001 \\
\text { Błąd std. estymacji: } 3.90\end{array}$} \\
\hline
\end{tabular}

Legenda:

A-O - postawa akceptacji-odrzucenia, „A”- agresywne radzenie sobie w sytuacji konfliktu społecznego.

Źródło: opracowanie własne. 
umiejscowienia kontroli w sytuacji sukcesów, gniew jako cecha osobowości, postawa akceptacji-odrzucenia matki oraz strategie agresji matki i ojca stosowane w sytuacji konfliktu społecznego. Współczynnik wielokrotnej determinacji wynosi R2 = 0,30 i wskazuje, że 30\% zmienności w zakresie strategii agresywnego radzenia sobie chłopców w sytuacji konfliktu społecznego daje się wyjaśnić oddziaływaniem przyjętego zespołu zmiennych niezależnych. Pozostałe zmienne uwzględnione w badaniu okazały się nieistotnymi wyznacznikami strategii agresji w grupie chłopców. Wartości beta świadczą, że im silniejsze przekonanie o kontroli zewnętrznej odnoszącej się do sytuacji sukcesów, im wyższy poziom gniewu rozumiany jako względnie stała cecha osobowości oraz im wyższy poziom postawy matki nasycony chłodem uczuciowym, dezaprobatą, wrogością, odtrąceniem wobec syna i im wyższy poziom strategii agresywnego radzenia sobie matki i ojca stosowanej w sytuacji konfliktu społecznego, tym wyższy poziom strategii agresywnego radzenia sobie chłopców w sytuacji konfliktu społecznego.

Podsumowując dokonaną analizę regresji, należy skonstatować, że przyjęte zmienne osobowościowe i rodzinne potwierdziły zasadność sformułowanej hipotezy H.1.

\section{DYSKUSJA}

Analiza wyników badań ujawniła, że sytuacyjna ocena określająca konflikt jako zagrożenie wiąże się ze strategią agresywnego radzenia sobie młodzieży w sytuacji konfliktu społecznego. Można przypuszczać, że sytuacyjna ocena konfliktu jako zagrożenia nasila strategię agresywnego radzenia sobie młodego człowieka w sytuacji konfliktu społecznego. Należy sądzić, że nastolatek, który znalazł się w sytuacji konfliktu społecznego i określający ją jako zagrożenie, skorzysta ze strategii agresji, aby poradzić sobie w tej sytuacji (Domińska-Werbel, 2014). Tendencja ta wydaje się zgodna z twierdzeniem L. Berkowitza (1992), że agresja powstaje w człowieku w rezultacie postrzeganego zagrożenia czy na skutek przekonania, że jest się obiektem intencjonalnego, niewłaściwego traktowania i naruszenia poczucia własnej wartości.

Przedstawione rezultaty badań wskazują także, że poziom samooceny odgrywa pewną rolę w wyborze strategii radzenia sobie w sytuacji konfliktu społecznego. Szczególnie dorastające dziewczęta zdają sobie sprawę ze swoich możliwości i ograniczeń, wpływających na ich sposób funkcjonowania w sytuacji konfliktu społecznego. Wyżej oceniają aspekty własnego ja, które bezpośrednio wiążą się ze stosunkiem do własnego wyglądu zewnętrznego i cech fizycznych. Można przypuszczać, że dla dziewcząt, które są sprawne fizycznie, strategia agresji staje się skuteczniejsza w radzeniu sobie w sytuacji konfliktu społecznego, a więc ma szanse utrwalić się dzięki swej instrumentalnej wartości (Wojciszke, 2000).

W toku analizy stwierdzono, że konfliktowe relacje $\mathrm{z}$ innymi (np. wzajemna niechęć, nieżyczliwość, obwinianie się), pojawiające się w społecznie zorganizowanym systemie działalności młodego człowieka, to formy zachowania współwystępujące najczęściej z poczuciem zewnętrznej kontroli. Silniejsze przekonanie o wpływie innych na pozytywne lub negatywne skutki własnych działań (kontrola zewnętrzna) sprzyja nasileniu strategii agresywnego radzenia sobie młodzieży w sytuacji konfliktu społecznego. Prawdopodobna wydaje się zatem prawidłowość, że brak wiary w możliwość uzyskania pożądanych rezultatów własnych działań czy brak poczucia odpowiedzialności za niepowodzenia sprzyja ujawnieniu przez młodzież strategii agresji w sytuacji konfliktu społecznego. Ponieważ młodzi najczęściej żywią przekonanie o niemożliwości wpływu na zmianę sytuacji konfliktu społecznego, więc nie wykazują koncentracji na źródle problemu, ale na sobie, nastawiając się na obronę zagrożonego ja. Powoduje to przyjmowanie strategii obrony w postaci agresywnego radzenia $\mathrm{w}$ sytuacji konfliktu społecznego i wzmacnianie jej przez rutynowe stosowanie w tej sytuacji (Borecka-Biernat, 2006; Rostowska, 2001).

Warto zaznaczyć, że młodzież stosująca w sytuacjach konfliktu społecznego strategię agresji przejawia wyższy poziom gniewu jako stanu emocjonalnego przeżywanego w związku 
z tą sytuacją i wyższy poziom wyuczonej dyspozycji do reagowania gniewem. Oznacza to, że im większe nasilenie strategii agresywnego radzenia sobie młodzieży w sytuacji konfliktu społecznego, tym wyższy poziom gniewu o zróżnicowanej genezie (stan, cecha). Podobny wynik w swoich badaniach uzyskały Danuta Borecka-Biernat i Grażyna Ciuladiene (2015), a także Dorota Domińska-Werbel (2014) i Joanna Kossewska (2008). Warto dodać, że wysoki poziom lęku o zróżnicowanej genezie (stan albo cecha) nie okazał się wyznacznikiem strategii agresywnego radzenia sobie dorastających w sytuacji konfliktu społecznego. Rezultat taki wydaje się odpowiadać konkluzji, którą sformułowała M. Tyszkowa (1986), że struktura osobowości jednostki i jej cechy decydują o tym, czy napięcie emocjonalne wywołane w sytuacji trudnej zostanie odczytane informacyjno-kompensacyjnie w stosunku do celu czynności, czy jako sygnał osobistego zagrożenia.

Ponadto analiza przedstawionych wyników badań ujawniła rolę odrzucającej postawy macierzyńskiej w kształtowaniu strategii agresywnego radzenia sobie w sytuacji konfliktu społecznego u dziewcząt i chłopców w okresie dorastania. Matka z powodu otwartej niechęci odczuwanej w stosunku do dziecka brutalnie odrzuca próby emocjonalnego zbliżenia z jego strony, unika kontaktu z nim i lekceważy jego potrzeby emocjonalne. Zatem dziecko nie doświadcza w swoim rozwoju ontogenetycznym otwartych, ciepłych relacji z osobą znacząca. Odrzucenie przez matkę wywołuje u dziecka stan silnego lęku, niepokoju połączonego z wrogością. Niepokój i wrogość są redukowane przez agresję, opór, negatywizm lub przez wycofanie się, bierność i apatię. Należy nadmienić, iż sposób reakcji dziecka na odrzucenie zależy między innymi od wzorców i norm funkcjonujących w rodzinie. Ponadto przy braku satysfakcjonującej więzi z matką dziecko określa otoczenie i świat jako nieprzyjazne, zagrażające, niebudzące zaufania, co skłania do koncentracji na sobie, gotowości obrony siebie i reagowania na doznawane frustracje między innymi nastawieniem na obronę własnego ja w formie zachowań impulsywnych, często agresywnych (Liberska, Matuszewska,Freudenreich, 2013; Poraj, 2002).
W toku analizy stwierdzono, że matka i ojciec spostrzegani są jako stosujący w sytuacjach utrudniających dążenie do celu strategię opartą na agresji, przyczyniają się do modelowania u młodzieży strategii agresji, wykorzystywanej w sytuacji konfliktu społecznego (Rostowska, 1996; Wolińska, 2013). Rodzice dostarczają dzieciom dorastającym agresywnych wzorów reagowania na konflikt. Córki i synowie uczą się tych wzorów przez obserwowanie zachowań matek i ojców w warunkach zagrożenia realizacji ich własnych dążeń. Młodzież przyjmuje z otoczenia rodzinnego agresywne formy zachowań i traktuje je jako skuteczne sposoby rozwiązywania problemów, osiagania celów czy też radzenia sobie z sytuacją konfliktu (Obuchowska, 2001; Patterson, 1986; Urban, 2005). Warto zwrócić uwagę na preferencję oddziaływań sprzyjających strategii agresywnego radzenia sobie dziewcząt i chłopców w wieku dorastania przez rodzica odmiennej płci. Można powołać się tu na zasady socjokulturowej teorii identyfikacji, głoszące, że wpływ na uspołecznienie dziewcząt i chłopców wywierają cechy osobowości tego z rodziców, z którymi dzieci się utożsamiają, a nie tylko fakt zgodności płci modela i identyfikującej się z nim osoby (Rychlak, Legerski, 1967).

Zreferowane wyniki badań potwierdziły słuszność przyjętej hipotezy badawczej. Uogólniając uzyskane wyniki, można stwierdzić, że poznawcze ustosunkowanie młodego człowieka do sytuacji konfliktu społecznego może mieć wpływ na wybór strategii zaradczej. Gdy sytuacja konfliktu społecznego spostrzegana jest jako zagrożenie, dorastający częściej stosuje strategię agresji. Należy także odnotować, iż młodzież stosująca strategię agresywnego radzenia sobie w sytuacji konfliktu społecznego wyżej ocenia aspekty własnego ja, które bezpośrednio wiążą się ze stosunkiem do własnego wyglądu zewnętrznego i właściwości fizycznych. Można przypuszczać, że strategia agresji u osób wyżej oceniających ja fizyczne staje się skuteczniejsza w radzeniu sobie w trudnych sytuacjach, a więc ma szanse utrwalić się dzięki swej instrumentalnej wartości. Silne przekonanie młodzieży o wpływie innych na pozytywne lub negatywne skutki zdarzeń odgrywa rolę w wyborze strategii agresywnego radzenia sobie w sytuacji 
konfliktu społecznego. Świadczy to o tym, że młodzież sięgająca po strategię agresywnego radzenia sobie w sytuacji konfliktu społecznego nie ma przekonania o możliwości uzyskania pożądanych rezultatów własnych działań, przypisuje je raczej pomyślnym splotom wydarzeń lub przychylności innych ludzi oraz nie potrafi wziąć odpowiedzialności za porażki, których przyczynę widzi w innych czynnikach zewnętrznych, na które i tak nie ma wpływu, np. w złym losie lub złośliwości innych ludzi. Zatem ocena sytuacji konfliktowej jako takiej, co do której młody człowiek jest przekonany, że nie ma nad nią kontroli, jest związana z agresywną formą radzenia sobie $\mathrm{z}$ tą sytuacją. Nie należy zapomnieć, że jednostka na sytuacje konfliktu społecznego reaguje emocjonalnie, może odczuwać gniew. Należy więc przypuszczać, że kiedy sytuacja konfliktu zostanie oceniona jako zagrożenie, i co do której młody człowiek jest przekonany, że nie ma kontroli nad jej przebiegiem, wyzwala to w nim gniew, co w konsekwencji wywołuje agresję. Strategia ta pomaga rozładować dorastającej młodzieży gniew pojawiający się w sytuacji stwarzającej zagrożenie dla realizacji ich własnych dążeń. Strategia agresji przede wszystkim stanowi formę radzenia sobie $\mathrm{z}$ gniewem odczuwanym w sytuacji konfliktu.

Ogólnie rzecz ujmując, człowiek w wieku dorastania, oceniający sytuacje konfliktu społecznego w kategoriach zagrożenia, zdający sobie sprawę ze swoich ograniczeń i mający przeświadczenie o braku możliwości oddziaływania na to, co się dzieje w tej sytuacji, będzie korzystał $\mathrm{z}$ agresywnych środków zaradczych, które uwolnią go, choć na krótki czas, od przykrego napięcia emocjonalnego, a które nie są ukierunkowane na rozwiązanie i przezwyciężenie trudności.

Nie sposób jednakże nie zauważyć, iż sposób nawykowego reagowania agresją młodzieży na emocje ujemne powstające w sytuacji konfliktu społecznego kształtuje niewłaściwa postawa wychowawcza charakteryzująca się uczuciowym dystansem rodzica w stosunku do dorastającego dziecka. Matki dziewcząt i chłopców wykorzystujących strategię agresywnego radzenia sobie w sytuacji konfliktu społecznego w percepcji własnych dzieci są chłodne emocjonalnie, nie okazują ciepła uczuciowego, są wrogo ustosunkowane, deprywują potrzeby emocjonalne, unikają kontaktu ze swym dorastającym dzieckiem i nie interesują się jego sprawami oraz poczynaniami. Nasilenie strategii agresji w sytuacji konfliktu dziewcząt i chłopców pozostaje w prostym związku ze stopniem frustracji ich potrzeb emocjonalnych (miłości i uznania, współdziałania i łączności z bliskimi osobami, bezpieczeństwa i pewności). Odrzucenie przez matkę wywołuje u dziecka stan niepokoju połączonego z wrogością, redukowanego przez agresję. Nie należy też zapominać, że proces modelowania odgrywa rolę w genezie nawykowego reagowania agresją na emocje negatywne, powstające w sytuacji konfliktu społecznego. Dorastający uczy się strategii agresywnego radzenia sobie w sytuacji konfliktu społecznego między innymi przez obserwowanie rodziców, którzy przejawiają taki sposób radzenia sobie w sytuacjach konfliktu społecznego i częsty z nimi kontakt, a więc przez uczenie się społeczne. Należy sądzić, że dorastające dzieci niedoświadczające w swoim środowisku wychowawczym akceptacji, otwartości na ich sprawy oraz wzorca zachowania aktywnego osób znaczących, dążącego do realnego rozwiązania konfliktu, nie potrafią radzić sobie w sposób skuteczny z sytuacjami konfliktowymi. Generalnie wydaje się, że dom rodzinny uczy młodego człowieka strategii agresywnego radzenia sobie w sytuacji konfliktu społecznego.

$\mathrm{Na}$ zakończenie rozważań trudno nie zauważyć, że poszukiwanie osobowościowych i rodzinnych uwarunkowań strategii agresywnego radzenia sobie młodzieży w sytuacji konfliktu społecznego wydaje się uzasadnione. Kwestia związków oceny poznawczej sytuacji konfliktu społecznego, samooceny, poczucia umiejscowienia kontroli, emocji, postaw rodzicielskich i wzoru reagowania rodziców na sytuację konfliktu społecznego to swoiste novum, z całą pewnością wymagające przeprowadzenia jeszcze wielu kolejnych badań w grupie młodzieży. Okazało się, że dobrane zmienne osobowościowe i rodzinne nie są silnymi predyktorami strategii agresywnego radzenia sobie młodzieży w sytuacji konfliktu społecznego, co oznacza, że może istnieć stosunkowo wiele in- 
nych zmiennych współdeterminujących poziom strategii agresywnego radzenia sobie młodzieży w sytuacji konfliktu społecznego. W przyszłości warto byłoby włączyć do klasycznej koncepcji M. Tyszkowej (1986) dodatkowe czynniki wewnętrzne i nowe zewnętrzne określające zachowanie człowieka w sytuacji trudnej. Nie należy jednak wykluczyć, że rezultaty tych analiz mogą okazać się początkiem badania dotąd pomijanych obszarów uwarunkowań strategii agresywnego radzenia sobie młodzieży w sytuacji konfliktu społecznego.

\section{BIBLIOGRAFIA}

Balawajder K. (2010), Zachowania uczestników konfliktu interpersonalnego. W: D. Borecka-Biernat (red.), Sytuacje konfliktu $w$ środowisku rodzinnym, szkolnym i rówieśniczym. Jak sobie radza z nimi dzieci i młodzież?, 137-179. Warszawa: Wydawnictwo Difin.

Berkowitz L. (1992), O powstawaniu i regulowaniu gniewu i agresji. Nowiny Psychologiczne, 1-2, 87-105. Borecka-Biernat D. (2006), Strategie radzenia sobie młodzieży w trudnych sytuacjach społecznych. Psychospołeczne uwarunkowania. Wrocław: Wydawnictwo Uniwersytetu Wrocławskiego.

Borecka-Biernat D. (2012), Kwestionariusz strategii radzenia sobie młodzieży w sytuacji konfliktu społecznego. Psychologia Wychowawcza, 1-2, 86-118.

Borecka-Biernat D. (2013), Kwestionariusz strategii radzenia sobie rodziców w sytuacjach konfliktu społecznego w percepcji dziecka. W: M. Straś-Romanowska (red.), Drogi rozwoju psychologii wroctawskiej. Tom jubileuszowy z okazji 45-lecia studiów psychologicznych w Uniwersytecie Wrocławskim, 223-245. Wrocław: Wydawnictwo Uniwersytetu Wrocławskiego.

Borecka-Biernat D., Čiuladiene G. (2015), Strategies for coping with situations of social conflict versus sex and age of Polish pupils of secondary schools in Vilnius. W: D. Borecka-Biernat (red.), Sytuacje konfliktu społecznego: przyczyny - sposoby rozwiazywania - skutki, 149-169. Wrocław: Wydawnictwo Uniwersytetu Wrocławskiego. Acta Universitatis Wratislaviensis. Prace Psychologiczne, 63.

Chandler L. (1986), The Stress Response Scale for Children: A Manual. Pittsburgh: University Press.

Czerwińska-Jasiewicz M. (2003), Społeczno-kulturowe podejście do dorastania. W: A. Jurkowski (red.), Z Zagadnień współczesnej psychologii wychowawczej, 208-226. Warszawa: Wydawnictwo Instytutu Psychologii PAN.

Domińska-Werbel D. (2014), Psychologiczne uwarunkowania strategii radzenia sobie młodzieży gimnazjalnej $w$ trudnych sytuacjach społecznych. Legnica: WPWSZ.

Drwal R. (1978), Poczucie kontroli jako wymiar osobowości - podstawy teoretyczne, techniki badawcze i wyniki badań. Materiały do Nauczania Psychologii, s. III, t. 3, 307-345.

Eysenck M. (2001), Sprawdź swoje lęki. Charaktery, 1, 29-30.

Gacek M. (2000), Niektóre osobowościowe determinanty odporności młodzieży akademickiej na stres psychologiczny - doniesienie z badań. Annales Universitatis Mariae Curie-Skłodowska, Vol. LV, Suppl. VII, No. 10, sectio D, 43-46.

Gross J., Halperin E., Porat R. (2013), Emotion regulation in intractable conflicts. Current Directions in Psychological Science, 22, 6, 423-429.

Guszkowska M. (2004), ...

Guszkowska M., Gorący A., Rychta-Siedlecka J. (2001), Ważne zdarzenia życiowe i codzienne kłopoty jako źródło stresu w percepcji młodzieży. Edukacja Otwarta, 4, 155-164.

Halloran E., Doumas D., John R., Margolin G. (1999), The relationship between aggression in children and locus of control beliefs. The Journal of Genetic Psychology, 160, 1, 5-21.

Harwas-Napierała B., Trempała J. (2000), Psychologia rozwoju człowieka, t. 2. Warszawa: Wydawnictwo Naukowe PWN.

Heszen-Niejodek I. (2000), Teoria stresu psychologicznego i radzenia sobie. W: J. Strelau (red.), Psychologia. Podręcznik akademicki, vol. 3, 465-493. Gdańsk: Gdańskie Wydawnictwo Psychologiczne.

Jackson S., Bistra J., Oostra L., Bosma H. (1998), Adolescent's perceptions of communication with parents relative to specific aspects of relationships with parents and personal development. Journal of Adolescence, 21, 305-322. 
Januszewska E. (2001), Style reagowania na stres w kontekście postaw rodzicielskich. Badania młodzieży w okresie adolescencji. W: D. Kornas-Biela (red.), Rodzina: źródło życia i szkoła miłości, 311-344. Lublin: Towarzystwo Naukowe KUL.

Jaworski R. (2000), Konflikt pokoleń w okresie adolescencji. Psychologiczne aspekty radzenia sobie ze stresem. W: R. Jaworski, A. Wielgus, J. Łukjaniuk (red.), Problemy człowieka w świecie psychologii, 27-54. Płock: Wydawnictwo Naukowe Novum.

Kępiński A. (1992), Lęk. Kraków: Wydawnictwo Sagittarius.

Kossewska J.(2008), Zasoby osobowe a agresja interpersonalna u młodzieży gimnazjalnej. W: H. WronaPolańska (red.), Zdrowie - stres - choroba w wymiarze psychologicznym, 145-159. Kraków: Oficyna Wydawnicza Impuls,

Krasowicz G., Kurzyp-Wojnarska A. (1990), Kwestionariusz do badania poczucia kontroli (KBPK). Podręcznik. Warszawa: Laboratorium Technik Diagnostycznych im. B. Zawadzkiego.

Krause N., Stryker S. (1984), Stress and well-being: the buffering role of locus of control beliefs. Social Science and Medicine, 18, 783-790.

Kubacka-Jasiecka D. (1986), Struktura ja a zwiqzek między agresywnościq i lękliwościq. Kraków: Wydawnictwo Uniwersytetu Jagiellońskiego.

Kulas H. (1986), Samoocena młodzieży. Warszawa: Wydawnictwa Szkolne i Pedagogiczne.

Kurtek P. (2005), Regulacyjna rola poczucia kontroli w radzeniu sobie młodzieży z niepełnosprawnością intelektualną lekkiego stopnia w sytuacjach trudnych. Przeglad Psychologiczny, 3, 277-294.

Lachowska B. (2010), Style rozwiązywania konfliktów i ich efekty w relacji między rodzicami i adolescentami - prezentacja narzędzi pomiaru. W: D. Borecka-Biernat (red.), Sytuacje konfliktu w środowisku rodzinnym, szkolnym i rówieśniczy. Jak sobie radzq z nimi dzieci i młodzież?, 180-206. Warszawa: Wydawnictwo Difin.

Lazarus R. (1986), Paradygmat stresu i radzenia sobie. Nowiny Psychologiczne, 3-4, 2-40.

Liberska H., Matuszewska M., Freudenreich D. (2013), Percepcja postaw rodzicielskich matek i ojców a zachowanie agresywne dorastających córek i synów. W: D. Borecka-Biernat (red.), Zachowanie agresywne dzieci i młodzieży. Uwarunkowania oraz możliwości ich przezwyciężania, 78-98. Warszawa: Wydawnictwo Difin.

Łaguna M., Lachowicz-Tabaczek K., Dzwonkowska I. (2007), Skala samooceny SES Morrisa Rosenberga polska adaptacja metody. Psychologia Spoteczna, 2, 164-176.

Łosiak W. (2009), Stres i emocje w naszym życiu. Warszawa: Wydawnictwa Akademickie i Profesjonalne.

Łukaszewicz M. (2002), Wpływ postaw rodzicielskich na poziom agresywności młodzieży. Wychowanie Na Co Dzień, 7-8, 14-16.

Miłkowska G. (2012), Agresja w okresie dorastania - charakterystyka, przejawy, przeciwdziałanie. W: Z. Izdebski (red.), Zagrożenia okresu dorastania, 91-110. Zielona Góra: Wydawnictwo Uniwersytetu Zielonogórskiego.

Miłkowska-Olejniczak G. (2002), Szkolne uwarunkowania zachowań agresywnych dzieci i młodzieży. W: A. Doliński (red.), Modelowe rozwiqzania działalności profilaktycznej w grupach dzieci i młodzieży, 57-70. Zielona Góra: Komenda Choragwi Ziemi Lubuskiej ZHP.

Narayan A., Chen M., Martinez P., Gold P., Klimes-Dougan B. (2015), Interparental violence and maternal mood disorders as predictors of Adolescent Physical Aggression Within the Family. Aggressive Behavior, 41, 253-266.

Nitendel-Bujakowa E. (2001), Lęki szkolne jako wyznacznik funkcjonowania dziecka. Problemy poradnictwa psychologiczno-pedagogicznego, 1, 15-37.

Obuchowska I. (2001), Agresja dzieci w perspektywie rozwojowej. W: M. Binczycka-Anholcer (red.), Agresja i przemoc a zdrowie psychiczne, 45-59. Warszawa-Poznań: Polskie Towarzystwo Higieny Psychicznej.

Obuchowska I. (2010), Adolescencja. W: B. Harwas-Napierała, J. Trempała (red.), Psychologia rozwoju człowieka. Charakterystyka okresów życia człowieka, t. 2, 163-201. Warszawa: PWN.

Ogińska-Bulik N. (2001), Zasoby osobiste jako wyznaczniki radzenia sobie ze stresem. Acta Universitatis Lodziensis Folia Psychologica, 5, 83-93.

Ostrowsky M. (2010), Are violent people more likely to have low self-esteem or high self-esteem? Aggression and Violent Behavior, 15, 69-75.

Patterson G. (1986), Performance models for antisocial boys. American Psychologist, 41, 432-444. 
Pawłów E. (1997), Twórcze strategie radzenia sobie z problemami życiowymi. Zeszyty Naukowe Uniwersytetu Szczecińskiego. Psyche, 1, 204, 201-212.

Plopa M. (2007), Psychologia rodziny: teoria i badania. Kraków: Oficyna Wydawnicza Impuls.

Polak K. (2010), Uczeń w sytuacji konfliktów szkolnych. W: D. Borecka-Biernat (red.), Sytuacje konfliktowe w środowisku rodzinnym, szkolnym i rówieśniczym, 23-40. Warszawa: Wydawnictwo Difin.

Poraj G. (2002), Agresja w szkole. Przyczyny, profilaktyka, interwencje. Łódź: Oficyna Wydawnicza Edukator.

Ranschburg J. (1993), Lęk, gniew, agresja. Warszawa: Wydawnictwa Szkolne i Pedagogiczne.

Rostowska T. (2001), Konflikt międzypokoleniowy w rodzinie. Analiza psychologiczna. Łódź: Wydawnictwo Uniwersytetu Łódzkiego.

Rostowska T. (1996), Transmisja międzypokoleniowa w rodzinie w zakresie zachowań agresywnych. Przegląd Psychologiczny, 39, 1-2, 177-186.

Rotter J., Chance J., Phares E. (1972), Applications of a Social Learning Theory of Personality. New York: Holt, Rinechart and Winston.

Różańska-Kowal J. (2004), Szkoła jako główne źródło stresu młodzieży w wieku dorastania. Kwartalnik Pedagogiczny, 3, 203-214.

Rychlak J., Legerski A. (1967), A sociocultural theory of appropriate sexual role identification and level of personal adjustment. Journal of Personality, 1, 36-38.

Scherer R., Coleman J., Drumheller P., Owen C. (1994), Assessment of Cognitive Appraisal and Coping Linkages Using Two Forms of Canonical Correlation. Dayton: Wright State University.

Skorny Z. (1987), Dziecko agresywne - objawy, przyczyny, przeciwdziałanie. W: W. Pomykało (red.), Vademecum dla rodziców dzieci od lat 6 do 10. Warszawa: Wydawnictwo Współczesne, 97-102.

Terelak J. (2001), Psychologia stresu. Bydgoszcz: Oficyna Wydawnicza Branta.

Turner A., White B. (2015), Contingent on contingencies: Connections between anger rumination, self-esteem, and aggression. Personality and Individual Differences, 82, 199-202.

Tyszkowa M. (1978), Sytuacyjno-poznawcza koncepcja odporności psychicznej. Przeglad Psychologiczny, $1,3-15$.

Tyszkowa M. (1986), Zachowanie się dzieci w sytuacjach trudnych. Warszawa: PWN.

Tyszkowa M. (1997), Odporność psychiczna. W: W. Pomykało (red.), Encyklopedia Pedagogiczna, 475-478. Warszawa: Fundacja Innowacja.

Urban B. (2005), Zachowania dewiacyjne młodzieży w interakcjach rówieśniczych. Kraków: Wydawnictwo Uniwersytetu Jagiellońskiego.

Winstok Z. (2007), Perceptions, emotions, and behavioral decisions in conflicts that escalate to violence. Motivation and Emotion, 31, 2, 125-136.

Włodarczyk D. (1999), Rola i miejsce oceny poznawczej w radzeniu sobie ze stresem. Nowiny Psychologiczne, 4, 57-73.

Włodarczyk D., Wrześniewski K. (2005), Ocena stresu w kategoriach wyzwania u chorych po zawale sercapróba syntezy na podstawie danych empirycznych. Przeglad Psychologiczny, 48, 339-358.

Włodarczyk D., Wrześniewski K. (2010), Kwestionariusz Oceny Stresu (KOS). Przegląd Psychologiczny, 4, 479-496.

Wojciszke B. (2000), Relacje interpersonalne. W: J. Strelau (red.), Psychologia. Podręcznik akademicki, vol. 3, 147-186. Gdańsk: Gdańskie Wydawnictwo Psychologiczne.

Wolińska J. (2000), Agresywność mtodzieży. Problem indywidualny i społeczny. Lublin: Wydawnictwo UMCS.

Wolińska J. (2013), Dynamika, profilaktyka i resocjalizacja agresji dzieci i młodzieży. W: D. Borecka-Biernat (red.), Zachowania agresywne dzieci i młodzieży. Uwarunkowania oraz możliwości ich przezwyciężania, 321-343. Warszawa: Wydawnictwo Difin.

Woźniak-Krakowian A., Wieczorek G. (2009), Przemoc w szkole jako zjawisko społeczne. W: A. WoźniakKrakowian, E. Napora, I. Gomółka-Walaszek (red.), Problemy marginalizacji dzieci i młodzieży, 115-150. Częstochowa: Wydawnictwo AJD.

Wrześniewski K. (1991), Trójczynnikowy inwentarz stanów i cech osobowości. Przeglad Lekarski, 2, 222-225.

Wrześniewski K. (1996), Style a strategie radzenia sobie ze stresem. Problemy pomiaru. W: I. Heszen-Niejodek, Z. Ratajczak (red.), Człowiek w sytuacji stresu. Problemy teoretyczne i metodologiczne, 44-64. Katowice: Wydawnictwo Uniwersytetu Śląskiego. 